\title{
Minimum Expectations of Tourists: An Essential Factor of Tourism Companies
}

\author{
S.J.Jadhav ${ }^{1}$ and Dr.V.S.More ${ }^{2}$
}

\begin{abstract}
Tourism industry has been accepted as the second largest industry after oil. The objectives of tourism development are to foster understanding between people, to create employment opportunities and bring about socio-economic benefits to the community3, (Govt.of India, National Tourism Policy, 1982). Enhancing lifetime value of tourism customers and developing a relationship with profitable customers has become the central focus of Tourism Company's strategy. It is a process of expectations and perceptions whereby a satisfied tourist experience a positive change in attitude towards the service2. The attempt has been made to explore the purpose of visit, food quality, and accommodation like Room Cleaning, Beddings, Ventilations and Destination guidance.
\end{abstract}

\section{Index Terms-Tourism, Religious Heritage, Hospitality}

\section{INTRODUCTION}

Tourism in a variety of countries that offers a source of identity building and cultural renewal to the people featured for visitors. Tourism being a service industry, it is necessary to enhance its service efficiency. The new policy will strive towards excellence by introducing professionalism through training and re-training of human resources and providing memorable visitor experience to both domestic and international tourists. Tourism industries provides various types of services - Accommodation services, Hotel and Railway Booking, Restaurants services, Hospitality, Recreational services, Communication and transportation services. Tourism generates considerable wealth and employment. The industry employs more than 200 million people worldwide. During the period of 1996 to 2006 foreign tourists arrival into India has drastically increasing trends. To manage all aspects of tourism implies retaining customers by providing appropriate services for them in time. The proposed study would emphasize on developing value attitude, purpose of visit, food quality, covering of destinations and Accommodations. Any customer, who has visited different destinations of tour, when they come back to home, tells to their friends, family members and relatives whether tour was successful or not successful.

${ }^{1}$ Lecturer, MVP'S, I.M.R.T., Gangapur Road, Nashik, Maharashtra, India(e-mail: subhashjadhav65@rediffmail.com, sjjadhav65@gmail.com).

${ }^{2}$ Director, MGV'S, IMR, Panchvati, Former Dean, University of Pune, Pune-7.

\section{Methodology}

Both primary and secondary data were collected for the present study. Primary data was collected with the help of questionnaire schedule used for 600 respondents. Secondary data was collected from published books, journals, private publications. Respondents covered from Nashik City, India in the experience of tourism. A simple description of facts in terms of frequencies and percentages has been used for the purpose of analysis. Chi-square test has been applied for data analysis.

\section{A. Sample Description}

For the purpose of Study tourists ware classified into Age and Education. On the basis of age a majority of respondents (41.00 percent) fell into the age group of $41-60$ years, while 36.33 percent fell into the age group of $21-40$ years. 1.17 percent fell into the lowest group and 21.50 percent fell into the group of 61-80 years.

On the basis of education, few respondents ( 6 percent) were uneducated, followed by 24 percent undergraduates, 30 percent graduates, 16 percent postgraduates, 3 percent professionally qualified, 4 percent diploma holders and 17 percent were others. On the basis of Income, 46.83 percent respondents fell into the income group of less than Rs. 20000 per month; followed by 19.83 percent in the income group Rs. 20000 but less than Rs. 29000 per month; and 10.83 percent in the group of Rs.30000 but less than 39000; the 6.17 percent income group of above Rs. 40000 .

\section{B. Customers Expectations}

Delivering consistent and superior service is an important expectation of customers. A customer contracting a customer service centre has a set of needs that must be fulfilled. There were some senior citizens, students, handicaps in tours. These customers required help to know market, help for purchasing of items, carrying bags, covers all destinations, medical aids, proper food and cleaned rooms for senior citizens. If agencies fail to fulfill their needs and expectations, they become unsatisfied. These customers will not come back to such traveling agencies for next tour.

\section{ANALYSIS}

\section{A. Customers Purpose of Visit}

Tourism has developed a culture of its own. Tourism in a variety of countries that also offer a source of identity 
building and cultural renewal to the people featured for visitors. Following figure no. 1 indicates that many of the customers go to different destinations for different purpose. Some lower class or medium class customers go to pilgrimage. Officials or educators go to conference and high Figure 1 economy class customers go for weekends either domestic or foreign tour. May be some customers go to take medical treatment in India or other countries. It is a duty of tour operator to solve the purposes of tourist's.

\section{Pie chart indicating customers purpose of visit}

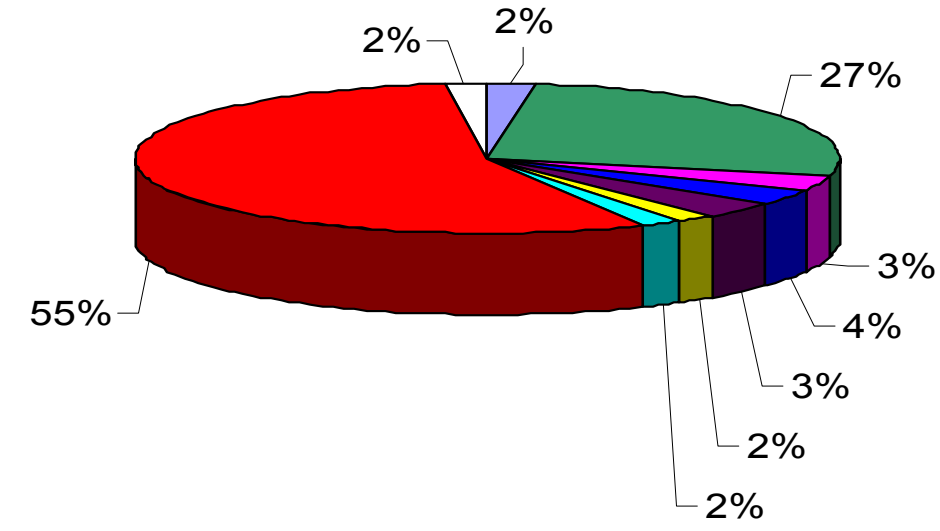

$\square$ Cultural program
$\square$ Weekends
$\square$ Visiting Friends and
Families
$\square$ Business
$\square$ Health Treatment
$\square$ Social function
$\square$ Conference
$\square$ Pilgrimage
$\square$ Others

Figure 1

From Figure 1, many of the customers go to different purposes as and when required. Out of 100 respondents, 55 percent of customers have visited to pilgrimage of different cities, 2 percent customers have visited for the purpose of conference either in India or abroad and 2 percent for social functions. 3 percent customers have visited for their health treatment and other 3 percent for meeting to their friends and families. 4 percent customers have visited for business purpose. Two percent customers have visited to cultural program and

2 percent for other purpose but 27 percent customers had visited for weekends. It means that maximum customers go outdoors either for pilgrimage or weekends but the area of minimum percentage of customers visit is cultural program, conference, and social function etc.

\section{B. Food Quality}

Much of the enjoyment in travel comes from dining out. Travelers consider food away from home, not just a convenience, but it is necessary1.The responses obtained were analyzed for tourist's experiences in connection with means of purpose of visit, food quality, and customer satisfaction etc.The respondents further asked to give their views about the quality of food served.

TABLE 1 TABUlated STATISTICS: FoOd Quality, CODE OF TRAV.AGENCY Rows: FoOD QuALITY COLUMNS: CODE OF TRAV.AGENC






\begin{tabular}{|c|c|c|c|c|c|c|c|}
\hline 1 & 12 & 7 & 7 & 8 & 9 & 11 & 53 \\
\hline 2 & 75 & 65 & 71 & 71 & 76 & 58 & 416 \\
\hline 3 & 8 & 12 & 14 & 12 & 8 & 8 & 62 \\
\hline Total & 100 & 100 & 100 & 100 & 100 & 100 & 600 \\
\hline
\end{tabular}

Table 1 indicates that out of 600 respondents 69 customers expressed that the food was not according to price but 62 customers gives their views about the food is costly but of good quality. Out of 100 respondents 58 customers from T6 tour says food was testy and delicious and from T1 tour, 75 respondents expressed the same. 7 customers from T2 and T3 tours expressed that the food was fresh.

Majority of the respondents expressed that the food was testy and delicious.The important thing is that the percentage of domestic tours is 81 percent and foreign tours are 19 percent. Out of $600,416(69.33 \%)$ respondents need is fulfilled and they are fully satisfied because their food quality was testy and delicious but 30.66 customers are not satisfied because no quality food. 53 percent respondents given a remark that food was fresh. Every customer required delicious and testy food. The tour agencies like T1 to T5 have given such quality food but T6 was unable to give quality of food, their food quality is not according to price. Out of 100 respondents, 14 percent respondents found it costly but of excellent quality of food. From Table 2, given the situation, Out of 600 respondents, full guided to 228 (48.00) customers But not given any guidance to

(143)23.83 customers. Provided partial guidance to 169 (28.17) customers. It's a worst case about such traveling agencies. It means that they are not taking care of customers

TABLE 2 -TABULATED STATISTICS: GUIDE PROVIDED, CODE OF TRAV.AGENCY during tour; they are very casual about customers. Before departure of tour every customer expect more from traveling Agency and if traveling agency is unable to provide good services, customers becomes unsatisfied. Maximum traveling agencies were not giving tour map, day's planning, place of halts. Customers are totally unaware about tours, total number of destinations like pilgrimages, sunrise, boating, hotels etc. Therefore customer's expectations were not fulfilled by Traveling Agencies. From Figure 2: It is summarized that, out of 100 respondents, guidance was not given for 24 percent customers, partial guidance given by guide is 28 percent and guide has given full guidance to 48 percent customers in tour. Each customer expecting more regarding destinations sites. Therefore it is a responsibility of every tour operator to show all destinations sites to customers, so that they become happy with those services. If customers are from rural place, agency authority should give map and information to such customers in their language. From Table 3, Out of 600 respondents, 218 tourist's accommodation arrangements was in Luxury class hotel but 191 tourist's stay was in Dharmashala and other 107 tourist's stay was in economical budget hotel. Tourist's expectations are very limited but majority of tourism agencies are not giving quality services to tourists.

\begin{tabular}{|c|c|c|c|c|c|c|c|}
\hline $\begin{array}{c}\text { Code of Travel } \\
\text { Aggencies }\end{array}$ & T1 & T2 & T3 & T4 & T5 & T6 & ALL \\
\hline Guide Provided & 13 & 23 & 23 & 25 & 31 & 28 & $\begin{array}{c}143 \\
23.83\end{array}$ \\
\hline 1 & 32 & 28 & 21 & 22 & 34 & 12 & $\begin{array}{c}169 \\
28.17\end{array}$ \\
\hline 2 & 55 & 49 & 56 & 53 & 35 & 40 & 228 \\
\hline Total & 100 & 100 & 100 & 100 & 100 & 100 & $\begin{array}{c}\mathbf{6 0 0} \\
\text { Agencies }\end{array}$ \\
\hline
\end{tabular}




\begin{tabular}{|c|c|c|c|c|c|c|c|}
\hline 1 & 32 & 28 & 21 & 22 & 34 & 12 & $\begin{array}{c}169 \\
28.17\end{array}$ \\
\hline 2 & 55 & 49 & 56 & 53 & 35 & 40 & 228 \\
48.00 & $\mathbf{4 0}$ \\
\hline Total & 100 & 100 & 100 & 100 & 100 & 100 & $\begin{array}{c}600 \\
100.00\end{array}$ \\
\hline
\end{tabular}

Rows: Guide provided Columns: Code of Trav.Agency

Cell Contents: Count \% of Column

Pearson Chi-Square $=21.099, \mathrm{DF}=10, \mathrm{P}-$ Value $=0.020$

Likelihood Ratio Chi-Square $=22.341, \mathrm{DF}=10, \mathrm{P}-$ Value $=0.013$

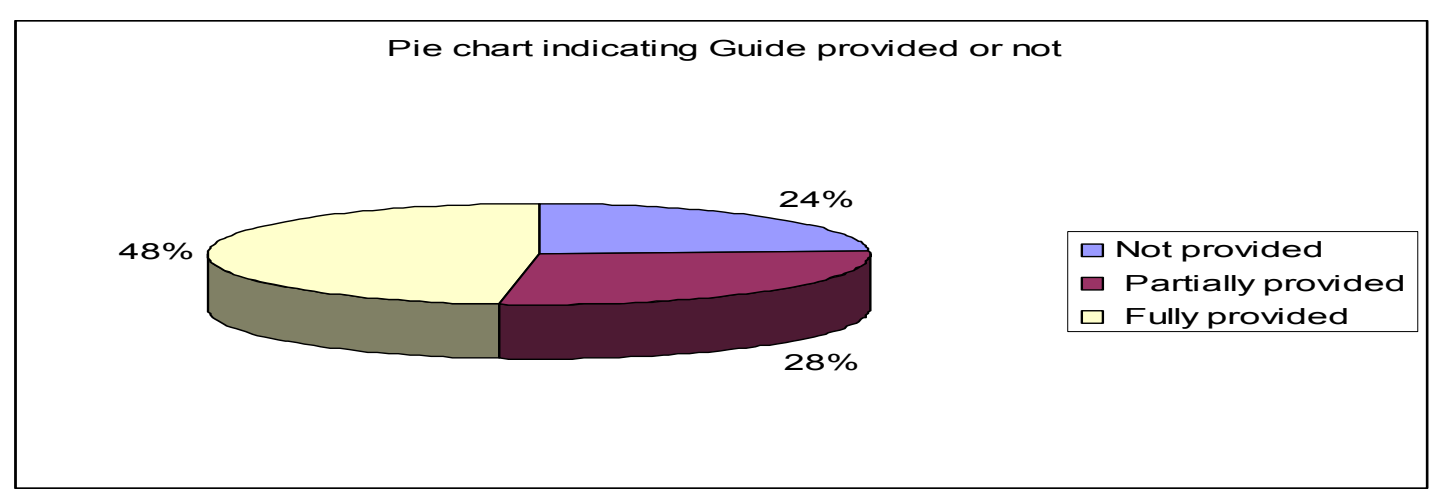

Figure 2

\section{Category of Tour and Accommodations}

From figure 3, researchers found that most of the customers choose domestic tours. There were very less number of customers who preferred foreign tours. Many of the customers are not going outside of India, they only prefer Indian culture. The maximum number of customers has selected domestic tours $(81.00 \%)$ and very less customers selects foreign tours $(19.00 \%)$. Accommodation is the basic need. From Figure 4, In case of accommodation, some tourist's rooms was not cleaned, no cleanliness of beddings and no proper ventilations made in such rooms. On the contradictory, most of tourism agencies given very cleaned rooms, good and cleaned bedding and appropriate ventilations to their existing customers.

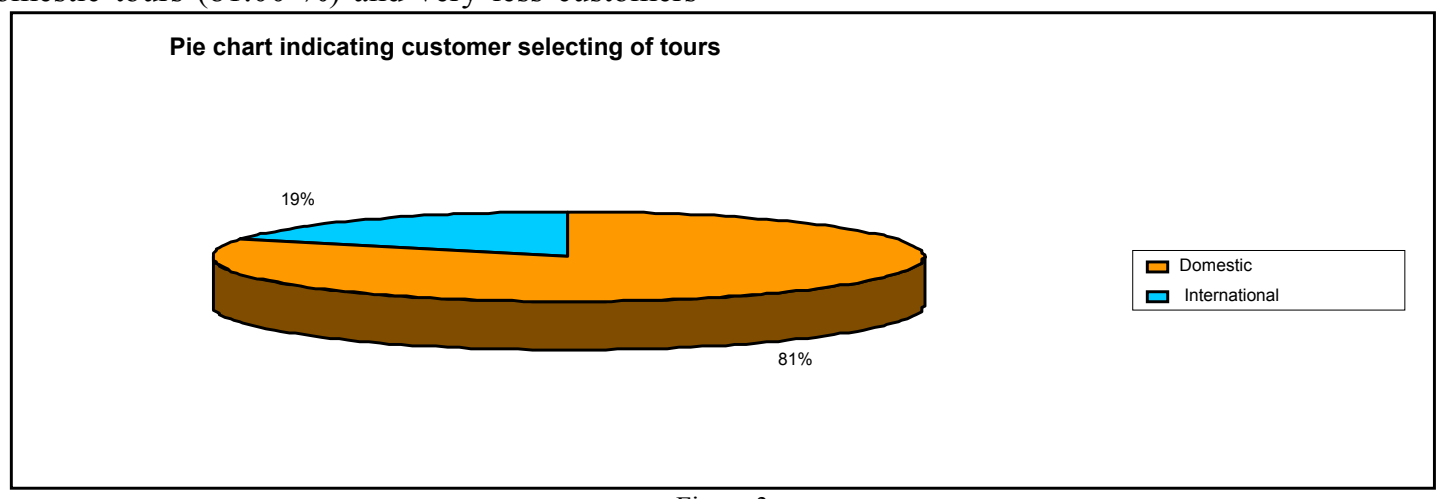

Figure 3

TABLE -3 .TABUlated STATistics: ACCOMMODATION, CODE OF TRAVELING AgENCIES.

\begin{tabular}{|c|c|c|c|c|c|c|c|}
\hline Accommodation & T1 & T2 & T3 & T4 & T5 & T6 & ALL \\
\hline $\mathbf{0}$ & 43 & 42 & 13 & 19 & 24 & 50 & 191 \\
\hline $\mathbf{1}$ & 1 & 0 & 5 & 2 & 5 & 4 & 17 \\
\hline $\mathbf{2}$ & 27 & 17 & 21 & 16 & 13 & 13 & 107 \\
\hline $\mathbf{3}$ & 11 & 17 & 3 & 5 & 18 & 13 & 67 \\
\hline $\mathbf{4}$ & 18 & 24 & 58 & 58 & 40 & 20 & 218 \\
\hline ALL & 100 & 100 & 100 & 100 & 100 & 100 & 600 \\
\hline
\end{tabular}

Cell Contents: Count \% of Column

Pearson Chi-Square $=115.856, \mathrm{DF}=20, \mathrm{P}-$ Value $=0.000$

Likelihood Ratio Chi-Square $=122.513, \mathrm{DF}=20, \mathrm{P}$-Value $=0.000$ 


\section{Chart indicating Performance of Rooms, Beddings and Ventilations}

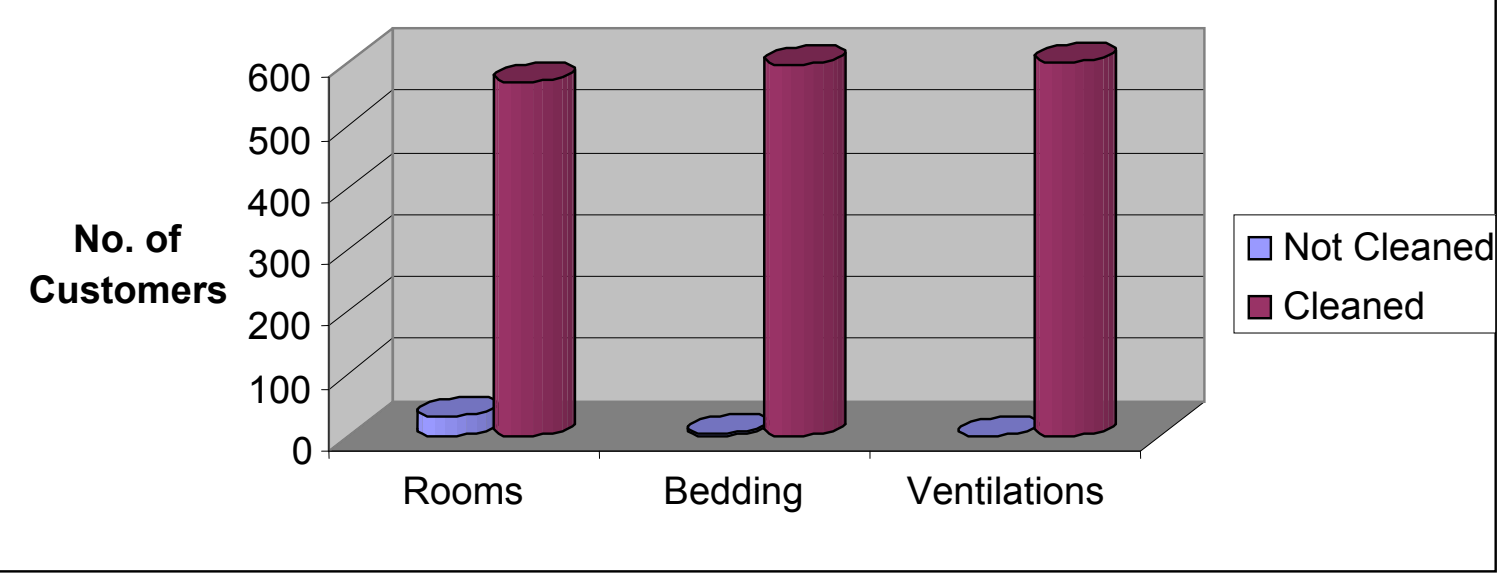

Figure 4

From Table 3, it is clear that, most of the traveling agencies have their own interest to maximize the profit. Very few traveling agencies i.e. T3, T4 and T5 given good accommodation in Luxury Class hotel and others are made accommodation either in Dharmashala or Economic class hotels. From Figure 4, for few tourists there was no cleanliness in rooms, beddings and no ventilations.

\section{CONCLUSION:}

Every tourists was expectations i.e. food quality, Covers all Destinations, well acquainted accommodations.

Some tour operators are successful by giving such services but other tour operators are not successful in such tourism services. Therefore positive thing was that 80 percent customers were fully satisfied with services provided by agencies. The quality was most important factor in this respect. It is common responsibility to identify customer's expectations, maintain standards, ethics and fare practices.
Every tour operator should facilitate safety and security of tourists.

\section{FUTURE WORK}

It is necessary to strengthen its promotional and marketing efforts and formulate marketing strategies to give high level discount, expand customer's network, and give better facilities to the tourist destinations. Facilitate safety and security of tourists. Standardized the tourism services.

\section{REFERENCES:}

[1] Gee Chuck, Makens James, Choy Dexter ( ),'The Travel Industry", John Wiley and son's publication, Third Edition

[2] The ICFAI Journal, 2008, "Management Research "The icfai University Press" Vol.6.

[3] National Tourism Policy, 1982, Govt.of India, Ministry of Tourism and Culture 